\title{
Effects of different scion-rootstock combinations on vigor, tree size, yield and fruit quality of three Iranian cultivars of pomegranate
}

\author{
Mohammadreza VAZIFESHENAS $^{1}$, Mehdi KHAYYAT ${ }^{2 \star}$, Salma JAMALIAN ${ }^{3}$, Alireza SAMADZADEH ${ }^{4}$
}

${ }^{1}$ Agric. Natur. Res. Cent. Yazd, Yazd, Iran

${ }^{2}$ Dep. Hortic. Sci., Coll. Agric., Birjand Univ., Birjand, Iran, mhdkhayyat@gmail.com

${ }^{3}$ Dep. Hortic. Sci., Coll. Agric., Shiraz Univ., Shiraz, Iran

${ }^{4}$ Dep. Crop Prod. Plant Breed., Coll. Agric.,

Birjand Univ., Birjand, Iran
${ }^{*}$ Correspondence and reprints

Fruits, 2009, vol. 64, p. 343-349 (C) 2009 Cirad/EDP Sciences All rights reserved DOI: $10.1051 /$ fruits/2009030 www.fruits-journal.org RESUMEN ESPAÑOL, p. 349
Effects of different scion-rootstock combinations on vigor, tree size, yield and fruit quality of three Iranian cultivars of pomegranate.

Abstract - Introduction. Probably because pomegranate trees are established in orchards as own-rooted plants, there are no studies regarding scion-rootstock combination effects on growth, tree size, yield and fruit quality of this fruit tree. Thus, the main aims of our experiment were to study the effects of some pomegranate rootstocks on growth and yield characteristics of Iranian commercial cultivars used as scions. Materials and methods. Our research was carried out between the 1999 and 2007 growing seasons at a collection of 760 pomegranate cultivars in the Yazd Province of Iran. Rootstocks were provided via clonal propagation using stem cuttings similar in height, diameter and age (2 years old) from 'Golnar Farsi', 'Torsh Ma' moly Zabol', 'Yek Killoy Hoshak Saravan', 'Poost Syah', 'Khafri Poost Sefid Jahrom', 'Zagh', 'Shavar' and 'Malas Esfahani'. Budding materials were provided from fruit-bearing trees in good vigor, using buds on current season growth of the 'Zagh', 'Shavar' and 'Malas Esfahani' pomegranate cultivars. Effects of the scion-rootstock combinations were investigated on tree size, vigor and yield of pomegranate. Results. The data indicated that grafting led to higher yield than the own-rooted plants, but grafted trees showed lower vigor and tree size compared with ungrafted trees. Application of 'Torsh Ma' moly Zabol' as a rootstock led to the lowest tree size and height, and the lowest rate of sunburn scald disorder. The highest yield and the lowest sucker production were obtained in plants grafted on 'Golnar Farsi' rootstock. Conclusion. Our results suggest that application of 'Torsh Ma' moly Zabol' as a rootstock can be useful to establish a high-density plantation.

Iran Islamic Republic / Punica granatum / rootstocks / scions / variety trials / yields / vigor

Effets de différentes combinaisons de scion/porte-greffe sur la vigueur, la taille de l'arbre, son rendement, et la qualité du fruit de trois cultivars de grenadier iranien.

Résumé - Introduction. C'est probablement parce que les grenadiers sont établis en vergers à partir de plantes simplement racinées qu'il n'a été publié aucun rapport sur les effets de la combinaison scion/porte-greffe sur la croissance, la taille de l'arbre, le rendement et la qualité du fruit de cet arbre fruitier. De ce fait, les principaux objectifs de notre expérimentation ont été d'étudier les effets de quelques porte-greffes de grenadiers sur des caractéristiques de croissance et de rendement de cultivars iraniens utilisés comme scions. Matériel et méthodes. Nos recherches ont été effectuées entre les périodes de production de 1999 et 2007 dans une collection de 760 cultivars de grenadiers de la province de Yazd en Iran. Les porte-greffes ont été obtenus par multiplication clonale à partir de boutures de dimension, diamètre et âge ( 2 ans) semblables, prélevées sur les cultivars "Golnar Farsi ", "Torsh Ma' moly Zabol ", "Yek Killoy Hoshak Saravan ", "Poost Syah ", "Khafri Poost Sefid Jahrom ", "Zagh ", "Shavar " et " Malas Esfahani ". Les scions ont été constitués par des boutures de l'année prélevées sur des arbres vigoureux et productifs appartenant aux cultivars de grenadiers "Zagh ", "Shavar " et " Malas Esfahani ". Les effets de la combinaison scion/porte-greffe ont été étudiés sur la taille, la vigueur et le rendement des grenadiers greffés. Résultats. Nos résultats ont montré que les arbres greffés produisaient un meilleur rendement que les arbres racinés, mais que la greffe induisait une taille et une vigueur des arbres inférieures à celles des arbres non greffés. L'utilisation de "Torsh Ma' moly Zabol " comme portegreffe a conduit à la plus basse taille des arbres, et à moins de coups de soleil. Le rendement le plus élevé et la plus basse production de pousses ont été obtenus par les plantes greffées sur le cultivar " Golnar Farsi ". Conclusion. Nos résultats suggèrent que "Torsh Ma' moly Zabol " pourrait être utilement utilisé comme porte-greffe pour établir une plantation à haute densité.

Iran République islamique / Punica granatum / porte-greffe / greffon / essai de variété / rendement / vigueur 
Table I.

Soil characteristics and weather conditions of the Agriculture and Natural Resources Research Center of Yazd (Iran).

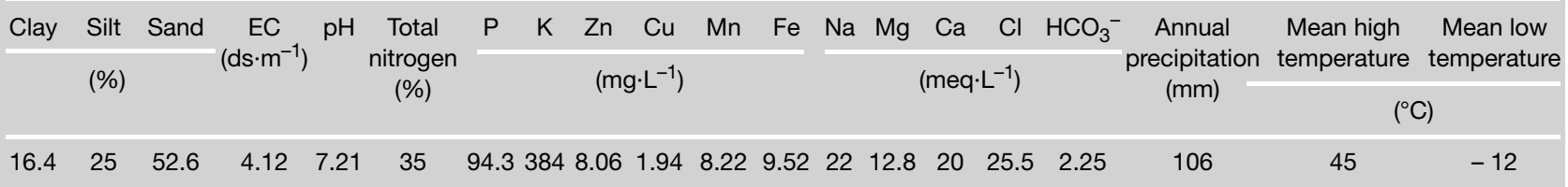

\section{Introduction}

Modern fruit growing creates an everincreasing demand for a variety of cultivars and rootstocks. The importance of rootstocks is more and more widely recognized, which, in terms of their influence on yield productivity, are not less important than the grafted scions. There have been many reports which showed that vegetative growth and growth habit depend on the genetic constitution of the plant and rootstock, environmental conditions or growing methods [1, 2]. However, how the rootstock controls scion growth is not fully understood. Kamboj and Quinlan suggested that hormones may be involved to control scion growth, and found a higher concentration of cytokinin in root exudates from vigorous rootstocks than from dwarfing ones [2]. Moreover, they showed a lower ratio of ABA to IAA in vigorous rootstocks than in dwarf rootstocks. Many reports showed that scionrootstock may be effective on growth, yield and fruit quality of tree plants. Kurlus in sweet cherry [3] and Son and Kuden in apricot [4] demonstrated that the rootstock significantly affected growth, yield and fruit quality. Szot and Meland reported that the rootstock strongly influenced fruits' external features, their size and the percentage of stone in total fruit weight in sweet cherry [5] Fallahi et al. found that the rootstock influenced the net photosynthesis, leaf nutrients and terminal shoot growth in apple trees [6]. However, there are no studies regarding scion-rootstock combination effects on growth, tree size, yield and fruit quality of pomegranate, probably because this plant is established in orchards as own-rooted plants.
The pomegranate (Punica granatum L., Punicaceae), a popular fruit and ornamental of Mediterranean peoples for centuries, native from Iran to the Himalayas, produces deliciously edible fruits. This plant is cultivated under dry weather conditions and saline lands in Iran, which confirms its tolerance to stressful conditions. Thus, the main aims of our experiment were to study the vegetative growth, yield and fruit quality of some Iranian commercial cultivars of pomegranate affected by rootstocks.

\section{Materials and methods}

\subsection{Planting}

An experiment was conducted, between the 1999 and 2007 growing seasons, with some cultivars from among the collection of 760 cultivars of pomegranate located at the Agriculture and Natural Resources Research Center (ANRRC) of Yazd Province (Iran) (table I). Eight rootstocks provided via colonial propagation using stem cuttings similar in height $[(30 \pm 0.5) \mathrm{cm}]$, diameter $[(2 \pm$ $0.2) \mathrm{cm}$ ] and age (2 years old) were used: 'Golnar Farsi', 'Torsh Ma' moly Zabol', 'Yek Killoy Hoshak Saravan', 'Poost Syah', 'Khafri Poost Sefid Jahrom', 'Zagh', 'Shavar' and 'Malas Esfahani'. In 1999, these materials were planted at a depth of $25 \mathrm{~cm}$ in sandy loam soil, prepared with essential amounts of manure and nutrients, in a rectangular pattern at $(3 \mathrm{~m} \times 4 \mathrm{~m})$ spacing.

After 2 years of planting, in the 2001 growing season, tube budding was done on rootstocks at a height of $15 \mathrm{~cm}$ above the 
Table II.

Some characteristics of some pomegranate cultivars (Yazd Province, Iran).

$\begin{array}{lccccccc}\text { Cultivars } & \text { Taste } & \text { Thorns } & \begin{array}{c}\text { Height } \\ (\mathrm{cm})\end{array} & \begin{array}{c}\text { Leaf length } \\ (\mathrm{cm})\end{array} & \begin{array}{c}\text { Fruit diameter } \\ (\mathrm{cm})\end{array} & \text { Skin color } & \text { Branch density } \\ \text { 'Golnar Farsi' } & \text { Ornamental } & \text { Few } & 200 \pm 5 & 4.5-5.0 & - & - & \text { Compact } \\ \text { 'Torsh Ma' moly Zabol' } & \text { Sour } & \text { Many } & 180 \pm 10 & 2-3 & 10 \pm 2 & \text { Full red } & \text { Compact } \\ \text { 'Yek Killoy Hoshak Saravan' } & \text { Sweet and sour } & \text { no } & 200 \pm 10 & 5-6 & 10 \pm 2 & \text { Full red } & \text { More compact } \\ \text { 'Poost Syah' } & \text { Sweet } & \text { no } & 180 \pm 10 & 6-7 & 10 \pm 2 & \text { Full red } & \text { Compact } \\ \text { 'Khafri Poost Sefid Jahrom' } & \text { Sweet and sour } & \text { Many } & 190 \pm 10 & 4-5 & 7 \pm 2 & \text { Low red } & \text { Compact } \\ \text { 'Zagh' } & - & \text { Few } & 200 \pm 10 & 7-8 & 7 \pm 2 & \text { Full red } & \text { Compact } \\ \text { 'Shavar' } & \text { Sweet } & \text { Medium } & 180 \pm 15 & 4-5 & 8 \pm 2 & \text { Pale red } & \text { More compact } \\ \text { 'Malas Esfahani' } & \text { Sweet and sour } & \text { Few } & 200 \pm 5 & 5-6 & 10 \pm 2 & \text { Full red } & \text { Compact }\end{array}$

Table III.

Number of the different scion-rootstock combinations (= 21 treatments) between nine cultivars of pomegranate used as rootstocks and three of them used as scions for studying the treatment effect on vigor, tree size, yield and fruit quality (Yazd Province, Iran).

\begin{tabular}{lccc}
\hline Rootstocks & \multicolumn{3}{c}{ Scions } \\
& 'Zagh' & 'Shavar' & 'Malas Esfahani' \\
'Golnar Farsi' & 1 & 8 & 15 \\
'Torsh Ma' moly Zabol' & 2 & 9 & 16 \\
'Yek Killoy Hoshak Saravan' & 3 & 10 & 17 \\
'Poost Syah' & 4 & 11 & 18 \\
'Khafri Poost Sefid Jahrom' & 5 & 12 & 19 \\
Without grafting (own-rooted tree) & 6 & 13 & 20 \\
'Zagh' & 7 & - & - \\
'Shavar' & - & 14 & - \\
'Malas Esfahani' & - & - & 21
\end{tabular}

soil surface to complete the tree constitutions of scion-rootstock. Budding materials provided from fruit-bearing trees in good vigor used buds on current season growth from the three commercial cultivars 'Zagh', 'Shavar' and 'Malas Esfahani'.

Conventional farm management including irrigation, fertilization and training was done during the experimental periods. However, because we decided to study the effects of rootstock on vigor and tree height, pruning was not done.

\subsection{Scion-rootstock combinations}

Many characteristics of the cultivars present in the ANRRC's collection were studied before choosing the best combination of pomegranate scion-rootstocks to be tested (table II). Cultivars utilized as scions were chosen based on vigor, fruit bearing and quality. In the end, twenty-one treatments were considered, each one corresponding to a scion-rootstock combination (table III). 
Table IV.

Effects of 'Zagh' pomegranate cultivars (scion) grafted on other pomegranate cultivars (rootstocks), on tree vegetative growth, yield and sunburn scald.

\begin{tabular}{lccccc}
\hline Rootstocks & $\begin{array}{c}\text { Tree height } \\
(\mathrm{cm})\end{array}$ & $\begin{array}{c}\text { Vigor } \\
(\mathrm{cm})\end{array}$ & $\begin{array}{c}\text { Sucker } \\
\text { No. }\end{array}$ & $\begin{array}{c}\text { Yield } \\
\mathrm{kg}^{-t^{-1} \mathrm{e}^{-1}}\end{array}$ & $\begin{array}{c}\text { Sunburn scald } \\
(\%)\end{array}$ \\
\hline 'Golnar Farsi' & $210 \pm 10$ & $310 \pm 10$ & 3 & $16.20 \mathrm{a}$ & $50 \mathrm{~b}$ \\
'Torsh Ma' moly Zabol' & $190 \pm 10$ & $280 \pm 10$ & 6 & $11.40 \mathrm{c}$ & $25 \mathrm{c}$ \\
'Yek Killoy Hoshak Saravan' & $200 \pm 10$ & $310 \pm 10$ & 6 & $14.20 \mathrm{ab}$ & $75 \mathrm{a}$ \\
'Poost Syah' & $200 \pm 10$ & $300 \pm 10$ & 6 & $12.00 \mathrm{~b}$ & $75 \mathrm{a}$ \\
'Khafri Poost Sefid Jahrom' & $200 \pm 10$ & $300 \pm 10$ & 10 & $14.60 \mathrm{ab}$ & $75 \mathrm{a}$ \\
'Zagh' (own-rooted) & $220 \pm 10$ & $350 \pm 10$ & 10 & $12.20 \mathrm{~b}$ & $50 \mathrm{~b}$ \\
'Zagh' (grafted with 'Zagh') & $200 \pm 10$ & $300 \pm 10$ & 10 & $15.00 \mathrm{ab}$ & $50 \mathrm{~b}$
\end{tabular}

Within each column, the same letter indicates no significant difference between treatments at the $5 \%$ level of LSD.

\subsection{Measurement}

We evaluated tree vigor, yield and sunburn scald on pomegranate trees from the 2001 to 2007 growing seasons. Tree height was assessed via measurement of a vertical line related to the soil surface, from the highest to the lowest point of the tree. Vigor was measured using annual shoot growth, and cumulative data are shown. As we did not study the effects of fruit bearing on vegetative growth, tree vigor was evaluated from the 2001 to 2005 growing seasons. Total yield $\left(\mathrm{kg} \cdot\right.$ tree $\left.^{-1}\right)$ was assessed from the 2005 to 2007 growing seasons and mean data was given. Sunburn scald is a general disorder in pomegranate growing which is strongly related to the canopy growth rate of trees, that protects the fruits from direct sun illumination. Thus, one hundred fruits per treatment were randomly chosen from the 2005 to 2007 growing seasons and mean data regarding sunburn scald were presented as percent.

\subsection{Statistical analysis}

Our experiment was arranged in a completely randomized block design with 21 treatments (= scion-rootstock combinations) and three replications, each consisting of five trees. Means were compared using least significant difference (LSD) tests at the $5 \%$ level.

\section{Results and discussion}

Analyzing the results, it appears that, whatever the cultivar considered ('Zagh', 'Shavar' or 'Malas Esfahani'), grafted trees showed lower size and vigor and higher yield compared with ungrafted treatments.

For the 'Zagh' cultivar used as a scion (table IV), the highest tree height and vigor were obtained from 'Zagh' without budding and the lowest ones from 'Zagh' grafted on 'Torsh Ma' moly Zabol', which is in agreement with Sottile et al. [7] but disagrees with Jacyna [8]. The lowest sucker production was obtained for 'Zagh' grafted on 'Golnar Farsi'. The highest yield was obtained from 'Zagh' grafted on 'Golnar Farsi' and the lowest one from 'Zagh' grafted on 'Torsh Ma' moly Zabol'. This result was in agreement with the findings of Kurlus on sweet cherry [3]. The lowest percentage of sunburn scald was obtained from 'Zagh' grafted on 'Torsh Ma' moly Zabol', which is positively correlated with tree vigor. This result was in agreement with those of Riesen and Husistein, who found that the rootstock influences apple fruit quality not only directly but also indirectly, affecting tree vigor and crop load [9].

For the 'Shavar' cultivar used as a scion (table $\mathrm{V}$ ), the lowest tree height and vigor resulted from grafting on 'Torsh Ma' moly Zabol' and 'Poost Syah' rootstocks, which 


\section{Table V.}

Effects of "Shavar" pomegranate cultivars (scion) grafted on other pomegranate cultivars (rootstocks), on tree vegetative growth, yield and sunburn scald.

\begin{tabular}{|c|c|c|c|c|c|}
\hline Rootstocks & $\begin{array}{l}\text { Tree height } \\
\text { (cm) }\end{array}$ & $\begin{array}{l}\text { Vigor } \\
(\mathrm{cm})\end{array}$ & Sucker No. & $\begin{array}{c}\text { Yield } \\
\mathrm{kg} \cdot \text { tree }^{-1}\end{array}$ & $\begin{array}{c}\text { Sunburn scald } \\
(\%)\end{array}$ \\
\hline 'Golnar Farsi’ & $200 \pm 10$ & $310 \pm 10$ & 3 & $17.50 \mathrm{a}$ & $50 \mathrm{~b}$ \\
\hline 'Torsh Ma' moly Zabol' & $190 \pm 5$ & $290 \pm 10$ & 6 & $14.40 \mathrm{c}$ & $25 c$ \\
\hline 'Yek Killoy Hoshak Saravan' & $200 \pm 15$ & $330 \pm 10$ & 10 & $17.60 \mathrm{a}$ & $75 \mathrm{a}$ \\
\hline 'Poost Syah' & $190 \pm 10$ & $310 \pm 10$ & 10 & $13.20 \mathrm{~d}$ & $75 a$ \\
\hline 'Khafri Poost Sefid Jahrom' & $200 \pm 15$ & $330 \pm 10$ & 10 & $14.00 \mathrm{c}$ & $75 \mathrm{a}$ \\
\hline 'Shavar’ (own-rooted) & $190 \pm 15$ & $330 \pm 10$ & 10 & $12.50 \mathrm{e}$ & $50 \mathrm{~b}$ \\
\hline 'Shavar' (grafted with 'Shavar') & $190 \pm 10$ & $310 \pm 10$ & 6 & $16.60 \mathrm{~b}$ & $50 \mathrm{~b}$ \\
\hline
\end{tabular}

\section{Table VI.}

Effects of 'Malas Esfahani' pomegranate cultivars (scion) grafted on other pomegranate cultivars (rootstocks), on tree vegetative growth, yield and sunburn scald.

\begin{tabular}{lccccc} 
Rootstocks & $\begin{array}{c}\text { Tree height } \\
(\mathrm{cm})\end{array}$ & $\begin{array}{c}\text { Vigor } \\
(\mathrm{cm})\end{array}$ & $\begin{array}{c}\text { Sucker no. } \\
\text { 'Gield }\end{array}$ & $\begin{array}{c}\text { Sunburn scald } \\
(\%)\end{array}$ \\
'Golnar Farsi' & $220 \pm 5$ & $340 \pm 10$ & 3 & $18.20 \mathrm{a}$ & $25 \mathrm{c}$ \\
'Torsh Ma' moly Zabol' & $190 \pm 10$ & $300 \pm 5$ & 6 & $15.40 \mathrm{ab}$ & $25 \mathrm{c}$ \\
'Yek Killoy Hoshak Saravan' & $210 \pm 5$ & $320 \pm 10$ & 6 & $16.20 \mathrm{ab}$ & $75 \mathrm{a}$ \\
'Poost Syah' & $210 \pm 10$ & $320 \pm 10$ & 6 & $13.30 \mathrm{~b}$ & $75 \mathrm{a}$ \\
'Khafri Poost Sefid Jahrom' & $210 \pm 5$ & $320 \pm 10$ & 10 & $15.60 \mathrm{ab}$ & $50 \mathrm{~b}$ \\
'Malas Esfahani' (own-rooted) & $220 \pm 5$ & $340 \pm 10$ & 10 & $13.20 \mathrm{~b}$ & $25 \mathrm{c}$ \\
'Malas Esfahani' (grafted with 'Malas Esfahani') & $210 \pm 10$ & $320 \pm 10$ & 10 & $17.40 \mathrm{ab}$ & $50 \mathrm{~b}$ \\
\hline
\end{tabular}

is in agreement with Sottile et al.'s results [7]. The lowest sucker production resulted from 'Shavar' grafted on 'Golnar Farsi', while the lowest yield was obtained from rooted 'Shavar', which proves the effectiveness of grafting. According to our results, it is clear that high-vigor rootstocks lead to higher yield than low-vigor ones. It may be due to the higher production of fruit-bearing positions in the tree canopy. The lowest percentage of sunburn scald resulted from 'Shavar' grafted on 'Torsh Ma' moly Zabol'. It is suggested that the compactness of 'Shavar' led to the lower rate of this disorder. This result is in agreement with those of Riesen and Husistein on apple trees [9].

For the 'Malas Esfahani' cultivar used as a scion (table VI), the lowest tree height and vigor were obtained from grafting on 'Torsh Ma' moly Zabol', which shows the effect of the rootstock on vegetative growth; this result is in agreement with Sottile et al.'s data [7]. The lowest sucker production was obtained from grafting on 'Golnar Farsi'.

According to our results (tables II, IV-VI), it is clear that trees constituted by 'Torsh Ma' moly Zabol', 'Poost Syah' and 'Shavar' showed lower height and vigor than the other cultivars studied. Particularly, 'Shavar' grafted on these cultivars led to the lowest height and vigor. Sucker production is a negative characteristic in fruit tree production. Our data (tables $I V-V I$ ) showed that the lowest number of suckers was obtained with the 'Golnar Farsi' rootstock. It is suggested that lower sucker production could prevent 
energy and carbohydrate loss, which would lead this rootstock to obtain higher yields.

\section{Conclusion}

Our experiment has a preliminary position in this pomegranate research area and requires further and broader research. Because 'Shavar' produces a lower leaf area and creates a more compact canopy than 'Zagh' and 'Malas Esfahani', it could be recommended to plant this cultivar for dry lands. Moreover, 'Torsh Ma' moly Zabol', 'Poost Syah' and 'Shavar' cultivars could be used as dwarfing rootstocks for breeding programs and to create high-density orchards.

In Iran, pomegranate plantations generally are located in dry and saline lands with low annual precipitation and high electrical conductivity of water and soil. Moreover, as the most utilized cultivars considered in our experiment are planted in Afghanistan, Armanestan and so on, the results of this experiment could be useful for recommendations for these other countries.

\section{References}

[1] Tromp J., Sylleptic shoot formation in young apple trees exposed to various soil tempera- ture and air humidity regimes in three successive periods of the growing season, Ann. Bot. 77 (1996) 63-70.

[2] Kamboj S.J., Quinlan J.D., The apple rootstock and its influence on endogenous hormones, Acta Hortic. 463 (1997) 143-152.

[3] Kurlus R., Rootstock effects on growth, yield and fruit quality of two sweet cherry cultivars in western Poland, Acta Hortic. 795 (2008) 293-298.

[4] Son L., Kuden A., Effects of seedling and GF-31 rootstocks on yield and fruit quality of some table apricot cultivars grown in Mersin, Turk. J. Agric. For. 27 (2003) 261-267.

[5] Szot I., Meland M., Influence of rootstocks on size distribution and fruit quality of sweet cherry cultivars, Int. Agrophys. 15 (2001) 207-214.

[6] Fallahi E., Chun I.J., Neilsen G.H., Colt W.M., Effects of three rootstocks on photosynthesis, leaf mineral nutrition, and vegetative growth of BC-2 Fuji apple trees, J. Plant Nutr. 24 (2001) 827-834.

[7] Sottile F., Monte M., De Michele A., Effect of different rootstock on vegetative growth of Japanese and European plum cultivars in southern Italy: Preliminary results, Acta Hortic. 734 (2007) 375-380.

[8] Jacyna T., The role of cultivar and rootstock in sylleptic shoot formation in maiden pear trees, J. Fruit Ornam. Plant Res. 12 (2004) 41-47.

[9] Riesen W., Husistein A., Influence of rootstocks on apple fruit quality, Acta Hortic. 466 (1998) 161-166. 


\section{Efectos de diversas combinaciones de ramo joven/porta-injerto sobre el vigor, el tamaño del árbol, su rendimiento, así como sobre la calidad del fruto de tres cultivares de granado iraní.}

Resumen - Introducción. Probablemente por causa de que los granados se establecen en vergeles a partir de plantas enraizadas de manera simple, que no se ha publicado informe alguno sobre los efectos de la combinación ramo joven/porta-injerto sobre el crecimiento, el tamaño del árbol, el rendimiento, así como sobre la calidad del fruto de este árbol frutal. Por consecuente, los principales objetivos de nuestro experimento fueron el estudio de los efectos que tienen ciertos porta-injertos de granados sobre las características de crecimiento y de rendimiento de cultivares iraníes empleados como ramos jóvenes. Material y métodos. Nuestros estudios se llevaron a cabo entre los periodos de producción de 1999 y 2007 en una colección de 760 cultivares de granados de la provincia de Yazd en Irán. Los porta-injertos se obtuvieron mediante multiplicación clonal a partir de esquejes de dimensión, diámetro y edad (2 años) semejantes, extraídos en los cultivares "Golnar Farsi ", "Torsh Ma' moly Zabol ", "Yek Killoy Hoshak Saravan ", "Poost Syah ", "Khafri Poost Sefid Jahrom ", "Zagh ", "Shavar " y "Malas Esfahani ". Los ramos jóvenes se constituyeron mediante esquejes del año, extraídos de árboles vigorosos y productivos, pertenecientes a los cultivares de granados "Zagh", "Shavar" y "Malas Esfahani ". Los efectos de la combinación ramo joven/portainjerto se estudiaron sobre el tamaño, el vigor, así como sobre el rendimiento de los granados injertados. Resultados. Nuestros resultados mostraron que los árboles injertados producían un mejor rendimiento que los árboles enraizados, pero que el injerto inducía tanto un tamaño como un vigor de los árboles inferiores a aquellos de los árboles no injertados. El empleo de "Torsh Ma' moly Zabol " en tanto que porta-injerto llevó al menor tamaño de los árboles, así como a menos quemaduras. El rendimiento más elevado y la producción más baja de brotes se obtuvieron mediante plantas injertadas en el cultivar "Golnar Farsi ". Conclusión. Nuestros resultados sugieren que "Torsh Ma' moly Zabol " podría emplearse útilmente en tanto que porta-injerto para establecer una plantación de alta densidad.

Iran República Islámica / Punica granatum / portainjertos / injerto de pua / ensayos de variedades / rendimiento / vigor 